ISSN (Online) 2710-3315

https://doi.org/10.20535/EHS.2021.233515

УДК 628.316 .12

\title{
ЗАБЕЗПЕЧЕННЯ ЕКОЛОГІЧНОЇ БЕЗПЕКИ ЕКСПЛУАТАЦІЇ ВОДНОГО ТРАНСПОРТУ
}

\author{
М.Б. Вознюк, Т.О. Шаблій \\ Національний технічний університет України \\ «Київський політехнічний інститут ім. Ігоря Сікорського» \\ пр. Перемоги, 37, Київ, 03056, Україна \\ e-mail: vozniukmarta@gmail.com
}

Водний транспорт, річковий та морський, є одним із джерел забруднення гідросфери. Це відбувається в результаті виникнення ряду факторів, таких як несанкціоновані скиди забруднених вод, недостатня очистка забруднених вод перед скидом, розливи палива в результаті аварій. Враховуючи зацікавленість економіки питанням більш ефективного використання водних (річкових та морських) шляхів для торгових перевезень, і відповідно збільшенням кількості суден, їх тоннажу, інтенсивності судноплавства на внутрішніх водних шляхах та морських прибережних районах України, питання попередження забруднення водних об'єктів постає все більш серйозною проблемою екології та безпеки.

Одним із основних та найбільш небезпечною забруднюючою гідросферу речовиною $\epsilon$ нафта, зокрема нафтовмісні води.

Хоча загальна кількість нафтовмісних вод, що скидаються із суден, в абсолютному вираженні мізерна в порівнянні зі скидами з нафтових танкерів, їх вплив на екологічний стан водного середовища значний.

За даними Державної служби статистики України показники [1] надходження нафтопродуктів (у тоннах) у моря та річки України зі зворотними водами у період 2009 - 2019 років наведено в табл. 1.

Хоча протягом даного періоду показники надходження нафтопродуктів до водойм знижувались, все ж таки вони залишаються досить високими.

У зв'язку з цим, а також посиленням норм та вимог до вмісту нафтопродуктів у водах, що скидаються до водних об’ єктів, питання ефективної очистки даних вод є актуальною задачею.

В результаті експлуатації водного транспорту, в ллялах машинних відділень суден відбувається утворення нафтовмісних вод [2]. На морських суднах дані води називають лляльними, а на річкових - підсланевими.

За визначенням Водного кодексу України, лляльна (підсланева) вода - вода 3 домішками (переважно нафтопродуктів), зібрана в колодязях - ллялах машинних відділень суден.

Основними джерелами утворення лляльних вод на борту судна є суднові двигуни, генератори і інші частини пропульсивних системи, такі як труби, насоси, механічні та експлуатаційні компоненти, встановлені в машинних приміщеннях суден. Відповідно до практики експлуатації, лляльна вода зберігається в трюмних колодязях, які періодично відкачуються. Накопичена лляльна вода переливається в резервуар для скидання в береговий 
(портовий) приймальний пункт або для очищення за допомогою бортового обладнання, призначеного для видалення нафти з лляльних вод перед їх скиданням за борт [3].

Таблиця.

Надходження нафтопродуктів (у тоннах) у моря та річки України зі зворотними водами у період 2009 - 2019 років

\begin{tabular}{|c|c|c|c|c|c|c|c|c|c|c|c|}
\hline $\begin{array}{c}\text { Природний } \\
\text { водний } \\
\text { об'єкт }\end{array}$ & 2009 & 2010 & 2011 & 2012 & 2013 & 2014 & 2015 & 2016 & 2017 & 2018 & 2019 \\
\hline $\begin{array}{c}\text { Азовське } \\
\text { море }\end{array}$ & 6,7 & 6,2 & 5,2 & 5,6 & 4,4 & 4,3 & 3,4 & 3,3 & 3 & 3,2 & 2,8 \\
\hline річки & 382,4 & 408,6 & 404 & 407,7 & 379,8 & 317 & 317,5 & 302,2 & 302,1 & 278,1 & 261,9 \\
\hline $\begin{array}{c}\text { Чорне } \\
\text { море }\end{array}$ & 6,8 & 7 & 6,2 & 7,3 & 6,6 & 1,4 & 0,7 & 2 & 1,5 & 1,3 & 1,2 \\
\hline річки & 283,9 & 255,8 & 191,4 & 187,5 & 173,2 & 247,6 & 231,5 & 191,4 & 169,1 & 154,7 & 147,1 \\
\hline
\end{tabular}

В даний час до складу лляльних вод входять важке паливо, мастило, масло для гідравлічних систем, миючі засоби, присадки до масел та хімікати [4].

В емульсіях лляльних вод зазвичай міститься до $50 \%$ частинок нафтопродуктів розмірами до 10 мкм, $25 \%$ - до 30 мкм, решта мають розміри від 30 до 200 мкм [5]. Вміст нафти в лляльних водах коливається в широких межах і залежить від багатьох факторів, таких як: тип суднових енергетичних установок, їх вік та технічний стан. В середньому нафтовміст лляльних вод становить не менш як 2000 млн $^{-1}$ для судів 3 ДВС і 1500 млн $^{-1}$ - для паротурбінних суден [2]. Склад нафтопродуктів, що містяться в лляльних водах, залежить від палива, що використовується на судні.

Для того щоб краплі нафти спливли, їх діаметр повинен бути більше 200 мкм. Застосування нафтових палив, щільність яких коливається в межах $0,83 \ldots 0,97$ г/см ${ }^{3}$, ускладнює очистку вод. Завислі речовини, що наявні в лляльній воді, є олеофільними, тому добре адсорбують нафту. Наявність поверхнево-активних речовин ускладнює процес поділу нафтовмісної емульсії [5].

Рядом нормативно-правових актів, як міжнародних, так і України, таких як: МІЖНАРОДНА КОНВЕНЦІЯ по запобіганню забрудненню з суден 1973 року (MARPOL 73/78), Водний Кодекс України, Правила охорони внутрішніх морських вод і територіального моря від забруднення та засмічення, Правила запобігання забрудненню з суден Регістра судноплавства України, Правила запобігання забруднення із суден внутрішніх водних шляхів України, Закон України «Про внутрішній водний транспорт України, Положення про державний санітарно-епідеміологічний нагляд, передбачено встановлення вимог до умов скидання у водні об'єкти забруднюючих речовин та до обладнання суден щодо запобігання забрудненню.

В загальному, вимоги даних документів зводяться до наступних:

- власники засобів водного транспорту, інші юридичні та фізичні особи зобов'язані забезпечувати охорону вод від забруднення і засмічення внаслідок втрат мастила, пального, хімічних, нафтових та інших забруднюючих речовин [6]; 
- $\quad$ у внутрішні морські води та територіальне море забороняється скидати з суден і плавучих засобів, платформ та інших морських споруд хімічні, радіоактивні та інші шкідливі речовини, а також відходи, матеріали, предмети та сміття, які можуть спричинити забруднення моря [6] [7].

- на внутрішніх водних шляхах України скидання із суден нафти, шкідливих речовин, залишків вантажу, сміття, забруднених і нормативно очищених вод не дозволяються [8].

- $\quad$ всі судна та інші плавучі засоби мають бути обладнані ємкостями для збирання лляльних та інших забруднених вод, які повинні систематично передаватися на спеціальні очисні споруди для очищення та знезараження [6] [8].

Виключенням є, відповідно до та 3 дотриманням вимог Конвенції МАРПОЛ 73/78 і резолюцією МЕРС.107(49), скид за борт у міжнародних водах очищених за допомогою суднових установок (сепараторів) лляльних вод з концентрацією нафтопродуктів не більше 15 млн $^{-1}$ [9].

На судні, що правильно експлуатується, буде присутня тільки невелика кількість лляльних вод за умови, що немає збоїв обладнання. Але навіть на судах з найкращим управлінням відбуваються поломки обладнання, що швидко призводить до забруднення лляльних вод і до збільшення їх кількості, і в будь-якому випадку існує необхідність їх очистки [10].

У вітчизняній і зарубіжній технічній літературі є достатньо публікацій стосовно технологій очищення нафтовмісних лляльних вод.

У зв'язку з різним вмістом нафти і морфологією лляльних вод, існують різні методи їх очищення. Сучасні технології очищення нафтовмісних лляльних вод в основному застосовують фізичні, фізико-хімічні, хімічні, біологічні та комбіновані методи очистки.

Найбільш простим способом і найчастіше першим етапом очищення води від нафтопродуктів, що містяться в ній, $є$ фізичний метод гравітаційного відстоювання. Гравітаційний метод ефективний для видалення основної маси нафти 3 суміші. Цей метод дозволяє видаляти 3 нафтовмісних вод практично всі грубодисперсні частки нафтопродуктів і очищати воду до концентрації в ній нафтопродуктів близько 100 мг/дм³ . Тому в більшості установок для очищення лляльних вод в якості першого ступеню очищення використовуються сепаратори, що працюють за принципом гравітаційного розділення середовищ, при цьому найбільш ефективним $\epsilon$ тонкошарові відстійники [11]. Але, оскільки він забезпечує видалення вуглеводневих компонентів лише 3 поверхневого органічного шару він є малоефективним.

Для видалення 3 лляльних вод колоїдних та дрібнодисперсних домішок, а також важких металів, фенолів, кислот, лугів застосовують фізико-хімічні методи, такі як адсорбція та флотація [12].

Метод очищення нафтовмісних вод флотацією полягає в насиченні об'єму води, що очищується, повітрям, бульбашки якого прилипають до частинок НП і, спливаючи, піднімають їх на поверхню розділу «вода - повітря» у вигляді нафтоповітряної піни, що легко видаляється [13].

Широке використання флотації для очистки лляльних вод обумовлено в першу чергу тим, що масла і нафтопродукти $є$ гідрофобними речовинами і легко піддаються флотації. Крім того, їх щільність значно менше щільності води, що також сприяє флотаційному поділу систем масло вода.

Дослідження показують, що флотація дозволяє зменшити вміст нафтопродуктів в лояльних водах до 2-5 мг/дм ${ }^{3}$ і нижче. При електрофлотаціі вміст нафтопродуктів менше 1,0 мг/дм³ [14].

Адсорбція є одним з небагатьох методів, що дозволяють очищати НСВ від дрібнодисперсних частинок нафтопродуктів незалежно від хімічної стійкості забруднень до мінімальних залишкових концентрацій. Це безінерційний рівноважний процес, що дає можливість успішно його використовувати як в стабільних умовах, так і в реальних умовах морського хвилювання [15].

Перевагами сорбційних методів $\epsilon$ їх сумісність з іншими способами збору нафтопродуктів та можливість багаторазового використання сорбенту після регенерації. У якості сорбентів використовують як природні (торф, активоване вугілля, тирса, перліт, глина), так й штучні (пінополіуретан, кераміка, синтетичні волокна) пористі матеріали [16]. 
Враховуючи те, що нафтопродукти є органічними речовинами, для глибокого очищення лляльної води можна використати процес окиснення. Процес очищення води із застосуванням окиснення це - хімічна реакція окиснення нафтопродуктів, що забруднюють воду, речовиноюокисником, наприклад озоном [17]. Очищення озонуванням засновано на високій окисній здатності атомарного кисню, який утворюється при мимовільному розпаді озону при нормальній температурі навколишнього середовища. Окиснення органічних речовин, що знаходяться в лляльних водах, при використанні озону набагато швидше і ефективніше (в 15-20 разів швидше i на $50 \%$ сильніше), ніж при хлоруванні. В процесі озонування одночасно відбуваються окиснювання органічних домішок, знебарвлення, дезодорація, знезараження води і насичення іiі киснем. Перевагою цього методу є те, що в воду додатково не вводяться забруднюючі хімічні реагенти [2].

Біологічні методи очистки передбачають використання вуглеводнеокислюючих мікроорганізмів, які здатні засвоювати різні вуглеводи нафти у якості єдиного джерела вуглецю. Перевагами біологічних методів $€$ їх ефективність, економічність, екологічна безпека та відсутність вторинних забруднень [12].

Сьогодні ринок пропонує широкий вибір систем очистки лляльних вод різноманітних модифікацій, що забезпечують достатній рівень даних вод.

Це можуть бути сепаратори лляльних вод різного типу - гравітаційного, флотаційного, коалесційного і комбінованого типу.

Як приклади можливо навести наступні існуючі системи очистки лляльних вод.

Система «HELI-SEP-500», що складається 3 двох ступенів: гравітаційного (гравітаційна матриця, в якій велика частина нафтопродуктів відділяється від води) та коалесційного (суміш проходить через упаковку поліпропіленових кульок, в якій залишкові нафтопродукти поєднуються і збираються в маслозбірній камері) [18].

Сепаратор нафтовмісних (лляльних) вод RWO SKIT / S-DEB - це гравітаційно-фільтруючий сепаратор вакуумного типу 3 коалесцирует елементом 3 додатковим елементом фільтрації і адсорбирующими картриджами [19].

Нафтоводяна фільтруюча установка «АКВАТЕХ» (двофазна), з використанням відцентрового, гравітаційного і коалесційного методів поділу середовищ «нафтопродукт-вода ». Ступінь очищення - менше 5 мг/дм³ у всьому діапазоні концентрацій нафтопродуктів [20].

Системи водоочистки Јowa - установка деемульгації - заснованої на процесі флокуляції (коагуляції) [21].

Система PureBilge компанії Alfa Laval - центробіжний сепаратор. Дана система дозволяє зменшити вміст нафтопродуктів у воді до $5 \mathrm{ppm}$ (parts per million). Система справляється 3 емульсіями, хімікатами, осадовими відкладеннями і продуктами корозії при очищенні і обробці води і здатна функціонувати в найскладніших і нестабільних умовах для їх обробки [22].

Однак, в умовах все більш суворих законів і стандартів щодо захисту навколишнього середовища, існуючі технології та системи очищення лляльних вод суден вже не можуть задовольнити попит. I в майбутньому тенденція розвитку технології очищення нафтовмісних лляльних вод суден буде рухатися в напрямку ефективності, захисту навколишнього середовища, енергозбереження та економії.

\section{Лiтература:}

1. Статистичний збірник «Довкілля України» за 2009, 2010, 2011, 2012, 2013, 2014, 2015, 2016, 2017, 2018, 2019//Державна Служба Статистики України. [Електронний ресурс]. - Режим доступу: http://www.ukrstat.gov.ua/druk/publicat/Arhiv_u/07/Arch_dov_zb.htm

2. Тихомиров Г. И. Технологии обработки воды на морских судах. Курс лекций: Учеб. Пособие для курсантов и студентов морских специальностей / Г.И. Тихомиров. - Владивосток.: Мор. Гос. Ун-т, 2013. - 159 с. 
3. An Alfa Laval white paper on oily water separation (2017). Bilge water compliance issues. [Електронний pecypc]. доступу: https://www.alfalaval.com/globalassets/documents/products/separation/centrifugalseparators/alfa-laval-purebilge-white-paper.pdf

4. Береза И. Г., Кучинская А. А., Петросян Е. И. Сорбционная доочистка судовых нефтесодержащих вод // Транспорт РФ. - 2012 . - № 2 (39). - С. 60-61

5. Справочник судового механика по теплотехнике / И. Ф. Кошелев, А. П. Пимошенко, Г. А. Попов, В. Я. Тарасов ; под ред. А. П. Пимошенко. - Л. : Судостроение, 1987. - 477 с.

6. Водний Кодекс України. Введений в дію постановою Верховної Ради України від 06.06. 95 № 214-95-BP

7. Про затвердження Правил охорони внутрішніх морських вод і територіального моря від забруднення та засмічення [Текст]: Постанова Кабінету Міністрів України від 29 лютого 1996 р. N 269

8. Про затвердження Правил запобігання забрудненню із суден внутрішніх водних шляхів України [Текст]: Наказ Міністрства транспорту та звязку України від 13.08.207 p. N 694

9. Резолюция МЕРС.107(49). Пересмотренные руководство и технические требования по оборудованию для предотвращения загрязнения из льял машинных помещений судов (Принятие от 18 июля 2003 года). [Електронний ресурс]. - Режим доступу: http://rise.odessa.ua/texts/MEPC107_49.php3

10. Сепаратор лояльних вод. [Електронний ресурс]. - Режим доступу: https://ru.googlinfo.com/8026684/1/separator-lyalnykh-vod.html

11. Зарецкая А.К Технология использования топлива, масла и воды: Курс лекций для студентов направления 6.070104 «Морской и речной транспорт» специальности «Эксплуатация судовых энергетических установок» дневной и заочной форм обучения - Издательство Керченского государственного морского технологического университета, Керч, 2014

12. Сучасні підходи до високоефективного використання засобів транспорту. Колективна монографія /за редакцією В.Чимшир/. - Ізмаїл : ДІ НУ «ОМА» 2020 - Київ: Міленіум, 2020. 472 с.

13. Тихомиров Г. И. Анализ методов и технических средств очистки льяльных вод / Г. И. Тихомиров // Транспортноу дело России. - 2015. [Електронний ресурс]. - Режим доступу: https://cyberleninka.ru/article/n/analiz-metodov-i-tehnicheskih-sredstv-ochistki-lyalnyh-vod/viewer

14. Справочник химика 21. Химия и химическая технология [Електронний ресурс]. - Режим доступу: https://www.chem21.info/article/404168/

15. Кучинская А. А. Технология очистки судовых нефтесодержащих вод с использованием природных сорбирующих материалов: дисс. канд. техн. наук. - Новоросийск, 2014

16. Сироткина Е.Е., Новоселова Л.Ю. Материалы для адсорбционной очистки воды от нефти и нефтепродуктов / Е.Е.Сироткина, Л.Ю.Новоселова // Химия в интересах устойчивого развития. - 2005. - № 13. - С. 359-337.

17. Решняк, В.И., Курников, А.С., Решняк, К.В. Исследование особенностей процесса окисления в дисперсной системе «вода-эмульгированные нефтепродукты» В.И. Решняк, А.С. Курников, К.В. Решняк // Журнал университета водных коммуникаций. Экология и охрана окружающей среды. - 2010. - №3. - С. 171-177.

18. Сепаратор льяльных вод. Судоремонт от А до Я. [Електронний ресурс]. - Режим доступу: http://sudoremont.blogspot.com/2014/04/separator.html

19. НОРТА МИТ МОРСКАЯ И ИНДУСТРИАЛЬНАЯ ТЕХНИКА [Електронний ресурс]. Режим доступу: http://norta.net/ru/catalog/separator-rwo/skit-s-deb.html

20. Для очистки нефтесодержащих вод. LOGISTICS.RU [Електронний ресурс]. - Режим доступу: https://logistics.ru/9/11/i20_1078.htm

21. Очистка сточных и льяльных вод. Морские системы и решения. [Електронний ресурс]. Режим доступу: http://www.marinesolutions.ru/ru/catalogue_water_cleaning.php

22. PureBilge. ALFALAVAL [Електронний peсурс]. - Режим доступу: https://www.alfalaval.ru/purebilge 